Cahiers $d u$ MONDE RUSSE

\section{Cahiers du monde russe}

Russie - Empire russe - Union soviétique et États indépendants

$53 / 4 \mid 2012$

Varia

\title{
Michael A. Reynolds, Shattering Empires
}

\section{David McDonald}

\section{OpenEdition}

\section{Journals}

\section{Electronic version}

URL: http://journals.openedition.org/monderusse/7860

DOI: 10.4000/monderusse.7860

ISSN: $1777-5388$

\section{Publisher}

Éditions de l'EHESS

\section{Printed version}

Date of publication: 15 December 2012

ISSN: $1252-6576$

\section{Electronic reference}

David McDonald, « Michael A. Reynolds, Shattering Empires », Cahiers du monde russe [Online], 53/4 | 2012, Online since 08 October 2013, Connection on 23 September 2020. URL : http:// journals.openedition.org/monderusse/7860 ; DOI : https://doi.org/10.4000/monderusse.7860

This text was automatically generated on 23 September 2020

(c) École des hautes études en sciences sociales 


\title{
Michael A. Reynolds, Shattering Empires
}

\author{
David McDonald
}

\section{REFERENCES}

Michael A. REYNOLDS, Shattering Empires. The Clash and Collapse of the Ottoman and Russian Empires, 1908-1918. Cambridge-New York : Cambridge University Press, 2011, XIV-303 p.

1 Michael Reynolds' impressive new study recounts the grinding Russo-Ottoman struggle in Anatolia and the Caucasus during the Great War that ultimately contributed to both empires' collapse. More important, Reynolds's account reframes radically and persuasively many longstanding assumptions about the relationship between the war and imperial collapse. Questioning the longstanding axiom that both states fell victim to modern nationalisms that sundered outdated imperial regimes, he traces their "shattering" to a vicious circle entrapping each of them. By the early twentieth century, Ottoman and Russian statesmen faced the two-sided challenge of domestic transformation through new forms of statecraft in order to uphold their security and survival in a remorselessly competitive international environment. These efforts, and the perspectives they sprang from, fell fatally short as they catalyzed the collapse they had sought to forestall.

2 Shattering Empires follows the careers of the Russian and Ottoman states during the years after 1908-1918, a period of domestic crisis, war, and collapse in both. In the Ottoman Empire, domestic reconstruction took on even more sweeping dimensions. The Young Turks who took power in 1908 -largely to forestall the seemingly impending loss of Macedonia - sought the creation of an assertive state, capable of mobilizing the population and revenues necessary to arrest the depredations of Ottoman territory and sovereignty by the Great Powers, not least Russia, and the new Balkan states formed by their one-time subjects. Following military defeat by Japan and 
constitutional reforms brought on by the revolution of 1905, Russian statesmen sought social renewal, economic expansion and rearmament as necessary conditions for what P.A. Stolypin called a "Great Russia."

3 These transformative programs drew on European methods of governance, which emphasized the use of a rationalizing and assertive state to create loyal modern subject-citizens and encourage economic growth, both of which could be efficiently mobilized in defense of national security. The Young Turks' practices imposed the state's direct presence in areas - most notably eastern Anatolia - long governed through the mediation of local notables. This approach to governance also incorporated a distinctive - and implicitly subversive - European understanding of nationality as the normative basis for statehood, a view dating at least to the Greek war of independence in the 1820s. The Treaty of Berlin had implicitly sanctioned the nation-state as the normative political unit, while establishing the welfare of so-called minority populations as an issue of international interest. These new norms brought unhappy consequences for the Ottomans, with recurrent interventions in the Armenian, and Macedonian "questions," as well as the Balkan Wars of 1912-1913, which saw the international acceptance of mass population transfers based on ascribed national belonging. To create an Ottoman nationality, the Young Turks sought to foster civic identification with the empire, downplaying the centrality of older confessional distinctions. Within Russia, the issue of national belonging emerged by the eve of the Great War itself, as older, inclusive notions of imperial loyalty were supplanted by the promotion of an increasingly exclusive notion of Russianness, even as "state" and "society" pursued a persistent political struggle over prerogative and legitimacy in the post-1905 order.

The Ottoman and Russian programs for domestic strengthening and mobilization depended, however, on the absence of international threat. The Young Turk revolution produced the opposite effect, provoking a series of challenges to international stability, beginning with the Bosnian crisis and Bulgarian independence in 1908, followed by the Balkan Wars, which also brought Russian security into question, as the German Empire became an increasingly supportive partner of the Ottomans. Reynolds argues - pace Sean McMeekin's recent Russian Origins of the First World War ${ }^{1}$ - that Ottoman leaders chose in October 1914 to join the Central Powers in war against Russia, expecting quick victory and the elimination of the most immediate threat to Ottoman security. This strategic calculation led instead to a draining conflict between the two eastern empires along a front stretching across eastern Anatolia, the southern Caucasus and along the Russian-occupied Persian borderlands.

$5 \quad$ As the war demonstrated, the attempt to mobilize national identity could also be used against one's adversaries. Reynolds documents Ottoman and Russian efforts to mobilize the "tribes" or "nationalities" in enemy territory against their Muslim or Christian overlords. The Russians funded Kurds or Armenians, while the Ottomans offered support to Muslim Azeris and Caucasian mountaineers. Yet, as Reynolds emphasizes, each side subordinated these subversive efforts to the primary security aim of establishing firm and viable strategic buffers against future threats from the other. By the same token, the mass population transfers legitimized during the Balkan Wars could become an instrument of domestic security policy, as illustrated most egregiously in 1915, when Talat Pasha ordered mass deportations of Armenians in eastern Anatolia. This tragedy owed as much to concerns for the security of borderlands inhabited by an 
untrustworthy minority population as to a genocidal hatred for Armenians as such the statecraft that privileged quantification and rational resource allocation helped make genocide possible.

6 The Russian revolutions of 1917 complicated the Ottomans' strategic goals, while demonstrating their geopolitical foundations. At Brest-Litovsk and during the Russian Civil War, the Turkish government championed the self-determination of Ukrainians and Caucasians, seeking bulwarks against the re-emergence of a powerful Russia. For their part, Russian commanders on the Caucasian front envisioned the seizure of large tracts in eastern Anatolia as a block to future Turkish expansionist designs. The subsequent Bolshevik leadership made their own appeals to Ottoman non-Turks in pursuit of security as much as proletarian internationalism. By the early 1920s, older notions of empire in both states had given way to radically different foundational principles - the supranational "class" aspirations of the Soviet state, on one hand, and the ardently Turkish nation-state imagined by the now-ascendant Mustafa Kemal, on the other.

7 Reynolds's account fills an important lacuna in western historical scholarship on the Great War and the shattering of the two eastern land empires in the European state system. The Russo-Turkish struggle has only recently begun to attract attention in English-language scholarship, including Mustafa Aksakal's Ottoman Road to War in 1914, Ronald Bobroff's Roads to Glory and Sean McMeekin's more problematic study, as well as Peter Holquist's work on the Russian occupation of Anatolia. ${ }^{2}$ With its strong command of Ottoman and Russian archival materials, Reynolds's work presents a rare comparison of the two empires' common dilemmas before the challenges of domestic and international insecurity. Given his training as an Ottomanist, Reynolds pays closer attention to that empire than to Russia, for which the Ottoman conflict posed less direct threat than the war against the Germanic empires to the west. One might also note that the domestic disruptions produced by state-sponsored transformation in response to apprehended international threats formed a motif for each empire's history after the Crimean War, which had brought the Ottoman Tanzimat and Russia's "Great Reforms." This cavil aside, Shattering Empires offers a cogent and well-made reminder to historians of modern Europe that the domestic challenges facing the Romanov and Ottoman empires arose from the imperatives of foreign policy as the impetus for domestic transformation, rather than from awakening nations rising to claim their own states.

\section{NOTES}

1. Sean McMeekin, The Russian Origins of the First World War, Cambridge: The Belknap Press of Harvard University Press, 2011, XII-324 p.

2. Mustafa Aksakal, The Ottoman Road to War in 1914: The Ottoman Empire and the First World War, Cambridge-New York: Cambridge University Press, 2008, XV-216 p.; Ronald Bobroff, Roads to Glory: Late Imperial Russia and the Turkish Straits, Londres-New York : I.B. Tauris, 2006, XII-251 p. ; Peter Holquist, « Forms of Violence during the Russian Occupation of Ottoman Territory and in 
Northern Persia (Urmia and Astrabad), October 1914-December 1917 », in Omer Bartov, Eric D. Weitz, eds., Shatterzone of Empires: Coexistence and Violence in the German, Habsburg, Russian, and Ottoman Borderlands, Bloomington-Indianapolis : Indiana University Press, 2013, p. 334-361. 